Abstracta Iranica Iranica

Revue bibliographique pour le domaine irano-aryen

Volume 25 | 2004

Comptes rendus des publications de 2002

\title{
Mardī ostovār va omīdvār be ofoq-hā-ye dūrdast. Mašhad, Tarāne, 1378/1999-2000?, 574 p.
}

\section{Tchanguiz Pahlavan}

\section{(2) OpenEdition}

1 Journals

\section{Édition électronique}

URL : http://journals.openedition.org/abstractairanica/5185

DOI : 10.4000/abstractairanica.5185

ISSN : 1961-960X

Éditeur :

CNRS (UMR 7528 Mondes iraniens et indiens), Éditions de l'IFRI

\section{Édition imprimée}

Date de publication : 15 mai 2004

ISSN : 0240-8910

\section{Référence électronique}

Tchanguiz Pahlavan, "Mardī ostovār va omīdvār be ofoq-hā-ye dūrdast. Mašhad, Tarāne,

1378/1999-2000?, 574 p. », Abstracta Iranica [En ligne], Volume 25 | 2004, document 336, mis en ligne le 15 mars 2006, consulté le 25 septembre 2020. URL : http://journals.openedition.org/ abstractairanica/5185 ; DOI : https://doi.org/10.4000/abstractairanica.5185

Ce document a été généré automatiquement le 25 septembre 2020.

Tous droits réservés 


\section{Mardī ostovār va omīdvār be ofoq-hā-ye dūrdast. Mašhad, Tarāne, 1378/1999-2000?, 574 p.}

Tchanguiz Pahlavan

1 Collected articles devoted to the memory of the late Ahmad Shah Massoud. These articles deal with different aspects of the history of Jihad and resistance in Afghanistan and the historical importance of Ahmad Shah Massoud.

2 The book consists of 16 chapters and an Appendix which is a chronology. There are a number of interesting photos and poems as well.

INDEX

Thèmes : 13.2. Afghanistan

\section{AUTEURS}

TCHANGUIZ PAHLAVAN

Münster 